\title{
At a crossroads: Uber and the ambiguities of the COVID-19 emergency in Lisbon
}

\author{
Giovanni Allegretti, Sheila Holz and Nuno Rodrigues
}

Giovanni Allegretti is a Senior Researcher in the Centre for Social Studies at the University of Coimbra, Portugal Sheila Holz is a Post-Doctoral Researcher in the Centre for Social Studies at the University of Coimbra, Portugal Nuno Rodrigues is a PhD candidate at the Instituto de Geografia e Ordenamento do Território (IGOT) at the University of Lisbon, Portugal.

\begin{abstract}
The emergence of the COVID-19 pandemic has brought to the surface some problems and trends within digital platforms, including working conditions, while simultaneously transforming the relationship between platform capitalism and the pandemic complex. Through the case analysis of Uber in Lisbon, we were able to identify a situation where several ambiguities emerged, some of which are associated with the Portuguese singularity of intermediary platform capitalism. From this analysis, anchored to several interviews with Uber drivers/partners, we observed that the pandemic crisis has aggravated some inequalities and problems generally associated with platform capitalism, but also seen new trends and solutions emerge for a political and socio-economic reformulation of this sector.
\end{abstract}

\section{KEY WORDS}

COVID-19, Uber, urban mobility, platform capitalism, GIG economy, workers' social protection, location-based platforms

\section{Introduction}

The COVID-19 outbreak has generated a series of descriptive books, written at speed, building superficial conjectures on epidemiologic statistics (Nath, 2020). These have been 
supplemented by important analyses, coming from academic and grey literature, that invite one to look at the disease as a pathology of society and no longer as a pathology of the body (Horton, 2020a). Among these reflections (Snowden, 2020; Santos, 2020b; Zizek, 2020), some view the emergency as a litmus test of the failure of the dynamics of neoliberal commodification and others as a catalyst for potential change in many dimensions of socioinstitutional life, in continuity and/or discontinuity with previous latent or patent trends.

In this perspective, MacKenzie (2020) observed that the new coronavirus revealed a paradox: that individuals matter, far beyond any value that science usually assigns them, within highly complex systems. This is valid, not only for essential workers (often depicted as new heroes ${ }^{1}$ ) and those 'wingmen' or 'supporting actors'2 who have proved fundamental to allow them to perform at their best, but for all caring individuals who demonstrate concern for personal and public wellbeing; and, in a certain way, also for some 'unscrupulous fraudsters' or members of elites who have capitalised on the pandemic for personal or political gain (Reitano \& Shaw, 2021).

Within the spectrum of these essential workers, in this article, we will focus on some of those operating within the scope of platform capitalism - namely, Uber drivers in Lisbon. In his seminal work on platform capitalism, Srnicek (2017) depicts the consolidation of digital platforms in the frame of a broader economic history, highlighting how they have emerged not only as technologically mediated structures, but also as responses to the crises of capitalism's profitability. His problematisation is important because it highlights the importance of data for the current economy - primarily as an answer to the profitability crisis - as well as providing a neat description of the way in which such platforms are constituted. Srnicek demonstrates how digital platforms position themselves and intermediate the actions of the different users connected through them. The business model is structured around, and supported by, that same intermediation, and the platforms' profits are proportional not only to the number of their users (network effects) but also to their capacity for instituting a set of rules (including, but not limited to algorithms) which structure the possibilities of action of the diverse agents who interact in and through the platform.

In such a perspective, this article uses evidence produced by the PLUS project, ${ }^{3}$ aiming to contribute to a better understanding of the effects of the pandemic in relation to the Uber platform, its workers and the regulatory framework that makes Portugal a unique case study in the context of platform capitalism. The analysis focuses on Portugal's capital, Lisbon, because it has an interesting and almost unique context, representing a laboratory for platform capitalism at a continental level (Tommasoni \& Pirina, 2019).

The authors wonder to what extent the pandemic crisis has aggravated pre-existing inequalities and whether it has originated new trends and solutions to address them in a modified socio-political and economic panorama.

\footnotetext{
1 See Sims (2020). https://www.bbc.com/worklife/article/20200422-will-coronavirus-change-howwe-define-heroes

2 These terms were used by an Uber Driver of Italian origin interviewed by the authors on 19 November 2020.

3 PLUS Project (Platform Labour in Urban Spaces), led by the University of Bologna and funded under the Horizon 2020 Programme. Grant agreement no 822638. For more information, see https://project-plus.eu/ the-project
} 
Addressing these questions from a qualitative methodological perspective, the narrative is anchored to 16 semi-structured interviews, conducted between March and December 2020, with Uber drivers and members of political institutions. The paper is organised as follows: the next section briefly frames the specificities of Portugal's and Lisbon's context. The third section explores the literature that interrogates the pandemic as a stage for the transformation of the activities of platforms. The next section describes some challenges posed by COVID-19 and how public institutions and digital platforms in Portugal faced them. The last two sections discuss some of the ambiguities and convergences of these transformations and summarise our findings and their implications for the challenging new period that is opening up for the functioning of the Uber platform in Lisbon.

\section{Before the pandemic: peculiarities of the Portuguese context and its regulatory framework}

Lisbon (a city with 509,000 inhabitants) constitutes a vital field of study, with a metropolitan area that hosts 2.86 million inhabitants and $44.4 \%$ of the whole immigrant population of Portugal, a population that is an important component of several activities linked to platform capitalism in a country that represents a key turntable for the absorption and distribution of immigration in Europe (Baganha, 2001). Here, the development of the platform economy is tied to 'startup urbanisation' (Carvalho \& Vale, 2018) with policies aiming to forge a smart city (Seixas et al., 2015), within a broader strategy of benchmarking connected to the digitalisation of the economy. In the mobility sector, decisions and the creation of a specific legal framework are centralised at the national level, although municipalities are exerting growing pressures on government and parliament, demanding an active role, especially in terms of having rights to access big data collected by companies. ${ }^{4}$

In recent years, there have been relatively few studies of Uber, and the dense ecosystem of digital urban transportation platforms using light vehicles. ${ }^{5}$ Nevertheless, the topic has become important because of the introduction in Lisbon, in 2017, of an Uber pilot Centre of Technology and Excellence, which provides support to trips across all Europe and tests innovations in Uber's offer, employing (by the end of 2020) almost 500 people, with more investments announced for the future. ${ }^{6}$

Uber initiated its activities in Portugal in 2016, after a troubled test period that started in 2014. ${ }^{7}$ Just a few months later, taking advantage of the situation created by a harsh conflict between the new platform and taxi drivers, the Ministry of the Environment created a Working Group to legalise electronic platforms in the transportation sector. This guided the development of Law 45/2018, which defines the

\footnotetext{
4 See Representative of Lisbon Mobility Department during Sopolab 1 - PLUS Portugal, held on 27 November 2020.

5 See, for example, Rodrigues et al. (2020); Leonardi \& Pirina (2020); Tomassoni and Pirina (2019).

6 See Rocha (2019). The number of employees was revealed by the Public Policy Manager Tomás Belchior during the event 'As plataformas digitais e o futuro do trabalho', organised by Colabor and ILO on 12 November 2020. See https://colabor.pt/agenda/12-novembro-2020-plataformas-digitais-futuro-trabalho/ 7 In July 2014 UberBlack service started in an unregulated context, being followed by UberX in December, and then blocked by a court for some months as a precautionary measure.
} 
legal framework in which Uber and other ride-hail apps operate. The Law's nickname ('Uber Law') illustrates the recognition of the platform's dominant self-imposed leading role in the transportation digital platform subsystem, opening a means for other companies (such as Chauffeur Privé ${ }^{8}$ and Bolt) to enter the market, having held back until the new legislation could offer 'balance and security to the investment that is being made' (LUSA, 2018).

The Uber Law's main feature is the introduction of a third party, an entity called a TVDE partner, ${ }^{9}$ between the platform and the worker. This TVDE partner may be either a company or a sole proprietorship (thus, often coinciding with the driver himself or herself). The law was designed to regulate the sector, including its labour market: therefore, it established that workers should have a contract with this third party, thus allowing them to obtain a labour contract. However, Law 45/2018 (the'Uber Law') has failed to meet its objectives in several ways (partly due to the lack of monitoring by some of the institutions in charge of it), and is currently under a scheduled revision - under the terms of the legal text itself (Art. 31). One of the main flaws in the enforcement of Law 45/2018 is precisely related to the status of workers, since the majority of drivers who work for Uber (and for other companies in the sector) operate as self-employed workers, in which capacity they are no longer allowed to work directly for platforms. Under the terms of the new law, many of them were forced to open a single-member company in order to be able to operate in the sector. According to IMT (Institute for Mobility and Transportation), to whom the task of issuing the TVDE licences was assigned, by 12 April 2021, 29,648 ${ }^{10}$ drivers had received their certificate for carrying out their activity through the 8,280 TVDE registered partners/ companies. ${ }^{11}$ No data are published on how many of these 'TVDE partners' are solely companies, how many are actually operative or whether they have just registered formally in order to be able to operate in the future. ${ }^{12}$

As already stated, no driver can work autonomously for a mobility platform. Although each driver needs a special licence to carry out his/her job, this can only be used if the driver also has a contract with a company (a TVDE partner) which Law $45 / 2018$ has imagined as an intermediary between those who operate through the platform (Uber drivers) and the platform itself. A TVDE partner company can be owned by the driver himself/herself, or not, but needs a specific registration, separate from the licence needed to be a driver.

This transformation, aligned with the dominant entrepreneurship culture in Portugal (rooted in family-based and micro-companies), brought into being a new

8 This company then became Kapten. The significant process of reshaping that characterised the mobilityplatform sector in Portugal in early 2019 saw Cabify ceasing operating, while Kapten was integrated into My-Taxy, a taxi service app, that was renamed as Free Now. Bolt is still operating.

9 The acronym TVDE means: remunerated and individual transportation on non-characterised vehicle via digital platform service (transporte individual e remunerado de passageiros em veículos descaracterizados a partir de plataforma eletrónica).

10 https://imt-tvde.webnode.pt/numero-de-certificados-de-motoristas-tvde/

11 http://www.imt-ip.pt/sites/IMTT/Portugues/Documents/TVDE_ListaDeOperadoresPorDenominacao.pdf

12 It is possible that several companies have just filed a formal registration, foreseeing a future saturation of the market, but they are not necessarily yet operative. 
Table 1: Profiles of workers and labour instruments in the Uber platform

\begin{tabular}{|c|c|c|c|c|}
\hline & \multicolumn{2}{|l|}{ Owned/loan } & \multicolumn{2}{|l|}{ Third party } \\
\hline \multirow{4}{*}{$\begin{array}{l}\text { 㞻 } \\
\stackrel{9}{\supset}\end{array}$} & \multicolumn{2}{|l|}{ TVDE Company } & \multicolumn{2}{|l|}{ TVDE drivers } \\
\hline & $\begin{array}{l}\text { Large business } \\
\text { entrepreneurs }\end{array}$ & $\begin{array}{l}\text { Company } \\
\text { profit }\end{array}$ & Freelance driver & $\begin{array}{l}\text { Percentual (Recibo } \\
\text { Verde/informal) }\end{array}$ \\
\hline & $\begin{array}{l}\text { Small Business } \\
\text { entrepreneurs/ } \\
\text { drivers }\end{array}$ & & Fulltime driver & $\begin{array}{l}\text { Fixed rate (Recibo } \\
\text { Verde/informal) }\end{array}$ \\
\hline & Self Employed & & Subordinated driver & Long term contract \\
\hline
\end{tabular}

(Source: PLUS Portugal, 2019)

contractual chain of digital platform $>$ TVDE partner company $>$ driver, shaping a hierarchical system with diversified levels of investment, sizes, managerial strategies and types of contracts (Table 1). This situation has resulted in a multiplication and overlapping of categories and situations. Most drivers work full time and have informal contracts, receiving a fixed rate for their work for a given TVDE company. There are a few cases of workers with a formal contract for a TVDE company, but precise statistics are not available, and it seems that the Portuguese state is not monitoring this situation with interest. In many cases, the full-time drivers own their own TVDE company being also Small Business Entrepreneurs: in this case, they may be the only worker for the company or have responsibility for the work of other drivers.

The peculiar relational model that characterises the ride-hailing sector in Portugal has been defined as 'intermediary platform capitalism' (Rodrigues et al., 2021) as it represents a 'hyper-outsourced model [...] that enables a monopoly rent to be gained' (Srnicek, 2017: 42), whereby workers, fixed capital, maintenance costs and even training are all outsourced. The optimisation of these multiple outsourcing mechanisms is granted mainly by the legalisation of the intermediary figures. The result is an atypical model based on a working relationship that is usually criticised as false self-employment, combined with a typical feature of platform capitalism, known as multi-apping, allowing customers/workers to switch between platforms according to their convenience.

Multi-apping (also named multi-homing) is common among accommodation providers (Gineikyte et al., 2020). However, in the transportation system the concept represents a new challenge because it questions the platforms' capacity to induce and maintain customer loyalty (Demary et al., 2020: 34) and even drivers' loyalty. In Portugal's case, the failure of competing platforms to combat the phenomenon of multi-apping (for instance, by contractually binding partners/drivers to exclusivity) has been strategically used as proof of the 'real self-employment nature' of the contractual relations between a provider and its drivers, as stated by a top Uber manager:

The service provided, although, it is truly an independent service [. . . It is anecdotal, but imagine a person who works in a restaurant, only showing up when he wants in one of the meals; when he arrives, he says he only cooks fish, and 
then he has the freedom - in the middle of a shift or working day - to work for the restaurant next door. This does not make sense for hired employment, but it is truly that autonomy that platform work allows. ${ }^{13}$

At the beginning of 2020, when the pandemic outbreak occurred, this intermediation system had already brought about a worsening ${ }^{14}$ of the precarious conditions of many workers. It had, for example, multiplied the number of cuts taken from client payments (the $25 \%$ taken by Uber was now added to other percentages due to the TVDE company). It had also failed to control working hours effectively, despite the legal requirement for daily workload limits to be regulated by law, with an obligation on companies to regulate and monitor the enforcement of the established limits. In practice, in the case of transportation platforms, respect for time limits is ruled algorithmically (through an automatic logoff imposed after ten hours have been worked in one day). Multi-apping became a way of evading this requirement, being used in practice as a tool that TVDE partners can use to push their drivers to extend their shifts, limiting the possibility of the control and the application of fines by public institutions (Tomassoni \& Pirina, 2019). The ambiguity of the TVDE legal framework also extends to the minimum value of each trip, which - according to Law 45/2018 - is supposed to allow for the recovery of operational costs by drivers: in fact, legislators have failed to define this value or update it, so that public control of this pivotal aspect of working conditions appears impossible in practice.

\section{COVID-19 as a revealer of (a usually unrecognised) embeddedness?}

The centrality of the human factor, and its specificity for each individual facing pandemic challenges (MacKenzie, 2020) seems especially meaningful in the gig economy, whose 'footloose workers' (Huws, 2006, 2014), often reduced to mere numbers (Khun, 2016), showed a higher degree of preparedness and resiliency to the pandemic than other non-gig workers (Polkowska, 2020; Raj et al., 2020; Spurk \& Straub, 2020; Stephany et al., 2020).

While wondering whether the COVID-19 factor aggravates the situation or perhaps - at least temporarily - leads to a certain reduction of the precarisation process (also named 'Uberisation'; Slee, 2017, 2016), there has been some reflection in the recent literature about the extent to which the pandemic offers a transformational opportunity (Sigala, 2020) of the platform economy's relations with workers and places. These discussions have, in particular, highlighted the artificial distance created between the platforms and the labour of service delivery through the self-positioning of many gig operators (especially gig giants such as Uber) as mere 'technology companies' and 'digital marketplaces', thus justifying the classification of their workers as 'independent contractors' rather than 'employees', which has facilitated the refusal of employment protections such as minimum wages and sick pay (Huws, 2019, 2020; Rami \& Dhir, 2020).

13 T. Belchior (2022) in the event 'As plataformas digitais e o futuro do trabalho' (12 November 2020): https:// colabor.pt/agenda/12- novembro-2020-plataformas-digitais-futuro-trabalho/ (minute 2:56-57).

14 See the Lisbon City Report - WP2 (Annex to D2.2) of PLUS Project delivered in November 2020. 
Katta et al. (2020) consider that COVID-19 is 'turning the world - and the world of work - on its head', compelling several gig companies, at least temporarily, 'to face up to the precarity of [their] drivers' work', reducing what Graham (2020: 1) defined as the strategic use of 'conjunctural geographies' - that is, a way of 'selectively existing at the conjuncture of multiple geographies' and 'of being simultaneously embedded and disembedded from the space-times [...] [a company] mediate[s]', thus circumventing labour laws, tax jurisdictions and even court systems of the localities it serves.

Somehow, during the first wave of lockdowns, the limited paid sick leave and other measures that companies such as Uber announced worldwide, despite the fact that they 'loosely resemble modest employment benefits' (Katta et al., 2020: 203), could be seen as a recognition that the strategy of disembedding from local norms and regulations 'has become harder to sustain' (ibid.: 203): therefore, they constitute a 'substantial departure from the company's usual position that it does not "employ" drivers, and that it is therefore not obliged to provide any benefits' (Katta et al., 2020: 204). From this perspective, the mounting public pressure that COVID-19 has placed on gig giants, especially on location-based platforms, has revealed that 'they have become an entrenched feature of urban life [contributing] to the daily making and remaking of local economic geographies, and [are] undeniably embedded into the fabric of the cities in which they operate' (Katta et al., 2020), wielding immense power over the lived experiences of their workers, determining their access to work, working conditions and remuneration (Rosenblat, 2018).

As Graham (2020) has argued, platform companies could have become more vulnerable precisely because of the embeddedness inherent within their model: in fact, to the extent that they are inextricable from the local, they end up providing a pathway to encoding local accountability into the gig economy's script. The COVID-19 pandemic (with its immeasurable human tragedy) has reinforced the gradual creation of new demands for accountability 'by reminding us of the materiality of the bodies [these companies] govern' (Katta et al., 2020). In such a situation, small signals of re-embeddedness and decommodification of the work factor can be read as a slow march towards a still unpredictable turn, which owes much to 'the intractable spatial tug-of-war with workers, unions, and regulators' (ibid.: 204) that several gig companies have started in the territories in which they operate. Possibly, the direction will be determined by the capacity of workers' struggles to appeal to social sensitivity to make progress towards social protection, an awareness of which the pandemic has awakened in rulers and the more general audience.

\section{Uber and the 'transportation ecosystem' during the pandemic}

\section{The state of emergency and its effects}

Since the beginning of the restrictions, on 18 March 2020, drivers have been allowed to work on the grounds that they are providing a service of public interest. Indeed, in the political discourse as in the public imaginary, ride-hail drivers and delivery riders have been reimagined as essential workers, assigned to this larger category where they overlap with others, a message reinforced in the giant outdoor displays in public spaces 
of the stay-home campaign. Despite this, TVDE drivers received low financial support, both from state and from their companies, and faced concrete difficulties and a plummet (UCSC, 2020) in their average incomes, linked to the sharp drop in demand, the costs of medical insurance and of COVID-19 tests and screenings, the strict requirements in terms of personal protection equipment (whose shortage was dramatic in the first two months) and the reduction of maximum vehicle capacity on each trip. The only costs which lowered 'were gasoline and the dead hours wasted in traffic jams, that disappeared. 15

With the pandemic, the precarious situation of drivers was worsened by risks due to

the nature of their work, as they cannot always ensure social distancing, depend entirely on task-based work for their earnings without paid sick leave, and they cannot afford to self-quarantine even if COVID-19 symptoms were to appear, posing risks to both themselves and others. (Rani \& Dhir, 2020: 168)

It is also likely that the peculiar way of governing the platform economy in Portugal could have resulted in a further weakening of social conflict through a divide et impera approach that tended to fragment the workers' front, while exacerbating the competition among the increasing number of available drivers and TVDE partners (which by the end of 2019 had reached peaks of 21,000 and 6,672, respectively, 3,873 being enterprises registered in Lisbon) as well as with 25,834 registered taxis. The limited data available show that, from April to June 2020, tax contributions from TVDE companies to the state fell by $71 \%$ compared to 2019. Between March and August, 151 companies closed (compared with 95 in 2019) and only 322 opened (compared with 1,583 in 2019). ${ }^{16}$ However, during the period of pandemic emergency, the absolute numbers of drivers grew, as is visible from the data displayed above related to the beginning of January 2021: in fact, many unemployed workers from other sectors saw a shock-absorber opportunity in mobility related jobs, thus increasing competition in the sector, exactly in a period of scarce demand.

By the end of 2019, collective practices of resistance and conflict concerning platform labour conditions remained scattered and intermittent, counting on informal associations of small TVDE partners ${ }^{17}$ and, later, on a group related to the General Confederation of Portuguese Workers (CGTP union). There was a multiplication of mutual support groups for sharing experiences on social networks (ILO, 2019), casting frequent doubts on their usefulness, since they appeared to be unreliable sources of information, when not actually boosting fake news (PLUS Portugal, 2019). However, they had a role in conveying the drivers' malaise, contributing to the first strike against the unilateral lowering of Uber fares, on 3-4 January 2020. And they also played an active role in a second massive strike which took place in the autumn, following a new unilateral lowering of Uber fares at the end of summer 2020.

15 Interview by the authors with a 36 years-old driver from Brazil (20 November 2020).

16 https://eco.sapo.pt/2020/10/09/ubers-estao-em-recuperacao-apos-grandes-quebras-da-pandemia/

17 Such as ANTUPE (National Association of Transporters using Electronic Platforms) or AEO TVDE (TVDE Operators Business Association). 


\section{Towards an oligopolistic re-configuration in the sector?}

Although the state institutions in charge have not collected and disaggregated useful statistics on it, our qualitative interviews revealed a clear tendency, emerging in connection with the pandemic, for small partners to exit from the TVDE system (accompanied by delicate situations of indebtment/loss of investment).

This trend has generated an oligopolistic reinforcement in the transportation sector, which rewards the TVDE companies with more cars, enabling them to dilute their costs (insurance, safety protection, high rates of dead hours with no rides, etc.) much more easily than small companies. Coupled with this trend, it is quite possible to imagine that these large companies, with stronger viability and bargaining power (and whose presence as partners make Uber's life easier), might tend to hire, preferentially or above all, people in a more precarious situation. In fact, workers such as immigrants or indebted persons (including those coming from previous experiences in TVDE mobility who are financially burdened) could be seen as easier to control. A partial counterbalance to such a trend is represented by the growth in the number of cars belonging to the XS category, created by Bolt for engaging drivers with small cars (such as FCA's Panda or Punto models), which are authorised by the rules set for the pandemic period to carry only one passenger at a time. This category allows drivers - with smaller investments - to use their own car, and free themselves from dependency on intermediary enterprises, while taking advantage of a general empoverishment of potential customers, which boosts the demand for lower transportation fares.

It seems possible that the pandemic accelerated trends which were already visible at the end of 2019, as suggested by a 45-year-old female driver who told us about:

the absence of any limitation on the number of drivers and TVDE companies, and of a minimum negotiated fare that could prevent competition among companies becoming a war to the bitter end for drivers, taking advantage of their strong need for survival, and using their fragmentation as a weapon against themselves. ${ }^{18}$

\section{A weak state response}

Beyond public safety campaigns (targeted at boosting client loyalty rather than assisting drivers), no measures of mass testing or promotions for facilitating specific healthcare insurances were undertaken by Uber (beyond a traditional insurance policy negotiated with AXA launched in $2018^{19}$ ); and the conventional levy that Uber imposes on rideinvoices remained at $25 \%$ (10\% more than its competitor Bolt). If TVDE workers were excluded from the government's extraordinary financial measures adopted in March $2020,{ }^{20}$ their reintegration in April 2020 specifically referred to cases with a drop in income greater than $40 \%$, with a maximum threshold of 438.81 euros per month, for up to six months. This measure was intended for 'self-employed persons', a category in which drivers are included in Portuguese legislation, even though they have often had great difficulty accessing this support.

18 Interview by the authors with a Brazilian driver, on 12 December 2020.

19 https://uberportugal.pt/portugal/partner-protection-pt/

20 See 'Extraordinary support for the reduction of the economic activity of self-employed workers'. http:// www.seg-social.pt/apoio-extraordinario-a-reducao-da-atividade-economica-de-trabalhador-independente 
Under international pressure to mitigate public health risks (Bellon \& Balu, 2020) and compensate government schemes for the self-employed that inadequately addressed gig workers' needs (Belger, 2020; Romo, 2020), in Portugal Uber announced a sickness subsidy for partners and drivers, contemplating compensation 'based on average weekly earnings for the last three months', up to 14 days if quarantined for COVID-19. ${ }^{21}$ Possibly attempting to maintain its reputation (Katta et al., 2020), the company's response, although inadequate and incrementally expanded under much criticism, ${ }^{22}$ involved a substantial deviation, if not an about-turn, from its normal modus operandi (ibid.), usually very defensive in relation to the business model exemplified in the tenets 'we are a marketplace' and 'we do not employ drivers' (Bellon \& Balu, 2020).

\section{Workers' reactions: associativism, multi-apping, protests}

A partial surprise in the wake of COVID-19 was the strength of the mutual support between drivers and TVDE companies, especially the smallest ones. In fact, the costs of some public health safety measures, which often weighed as a heavy burden on drivers, were frequently shared with TVDE partners, while drivers partially shared 'the financial exposure of intermediary enterprises with respect to car leasing and other kinds of instrumental costs' (Rodrigues et al., 2021).

It is worth stressing that, as several TVDEs work on multi-apping schemes with several platforms at the same time,

the request of Uber competitors (such as Bolt and Freenow) also had to be applied, thus raising the bar of standard requirements. One example of this was the acrylic barriers separating passengers and drivers, which were initially implemented at the initiative of some drivers or TVDEs, and became compulsory for other platforms [before Uber itself required it]. (ibid.: 4)

Requests for pictures wearing facemasks, and repeated questions formulated by the app before services, completed the pressure on drivers (and partially on customers) to guarantee the construction of a safe environment, under threat of account deactivation.

Such developments undoubtedly imply a direct relation of cause and effect with the COVID-19 outbreak. However, for some other transformations which occurred during 2020 in the sector, the pandemic was just a contributing cause, which possibly accelerated or slowed down trends that were already taking shape. Among these, it is worth highlighting the measure, adopted on 29 October in response to the growing competition with other operators (such as Bolt, which had recently introduced the

\footnotetext{
21 https://www.uber.com/pt/blog/update-covid-19-financial/

22 As Katta et al. (2020) refer to when analysing the global measure adopted by Uber, 'on March 7, 2020, it implemented a global financial assistance policy to support drivers diagnosed with COVID-19 with up to 14 days of paid sick leave' (see, also, Kerr, 2020). 'This policy was not without flaws, with drivers reporting that the payment was inadequate, that rollout has been delayed and patchy, and that it involved onerous qualification conditions, such as consenting that the payments would not change their employment status' (see, also, Sonnemaker, 2020).
} 
cheap fare 'XS' for small city cars) in a suffering market: to reduce unilaterally the ride-fares in Lisbon's metropolitan area, through the creation of a multiplier to adjust rates. ${ }^{23}$ Presented as a 'completely optional and flexible option', changeable at any time, ${ }^{24}$ it was envisaged by workers as a 'dumping', in tariffs that penalised drivers and TVDE companies, transferring the responsibility of cost reduction onto them. This choice represents a discharge of liability for Uber in case of contestations referred to at the request of Law 45/2018 to maintain ride prices within a value that allows cost-recovery on the part of drivers: in fact, the drop in the cost of a ride almost appears as a decision made by drivers themselves, rendering invisible the way that any decision not to lower the price will be a 'core input' for the algorithm which uses this information to calculate how to distribute the next rides. Such situations demonstrate the way that in Portugal digital platforms carry out trade wars with each other in search of a higher market share, resulting in a drop in income for drivers and TVDE companies, which carry the majority of costs in this type of lean economy.

A slow march of protest on 6 November gathered 500 participants, and a smaller one on 26 November presented a dossier of claims to the parliament, alleging a violation of Law 45/2018, which requires previous negotiations with workers on important topics, particularly in relation to the untransparent management algorithm that attributes rides first to those that reduce their fares most drastically, revealing that optionality is a lie. Uber's partial back-down after these protests (demonstrated by its restoration of the minimum fare for short trips) can be seen as part of a permanent tug-of-war, well described by a 40 -year-old driver:

For us workers it was a test of strength. Uber partially backs off, but it's not a victory for us, because the multiplier is still there and the competition for clients and market spaces among the companies is gory. No newspaper writes about our struggle. So, Uber smiles because they are only interested in retaining customers' loyalty by advertising the good news of cheaper prices, no matter if it is partially revoked [. . .] But we defend ourselves, using other apps as they treat us better than Uber [. . . I I am sure we will capitalise on this confrontation to get stronger support from the government and parliament, when we are getting closer to the revision of the 'Uber Law'. Luckily, the revision was postponed by COVID, because it will take place at a time when we are made stronger by months of common despair and mutual support, and Uber is weak: for the crisis, to tactical mistakes and because they do not understand that having a special law in their name bears responsibilities, that they will one day be asked to account for [. . .]25

As the interviewee synthesised so well, workers have addressed these difficulties through a set of diverse strategies. The first of these involves more effective forms of collective organisation that have matured during a period when, as is also the case

23 Now, fares in Lisbon were: $€ 0.90$ base rate, $€ 0.09$ per minute and $€ 0.59$ per kilometre. The Art. 15 of Law $45 / 2018$ say that 'final prices should cover all costs associated with the service', but threshold values have never been established.

24 See https://www.uber.com/pt/blog/lisbon/motoristas-ja-podem-definir-as-suas-tarifas/

25 Interview with a Portuguese Uber driver with a small enterprise of two cars, collected on 2 December 2020. 
in some other sectors, social movements and claims for basic rights have increased (Mendes, 2020) and there is a willingness to build alliances in the institutional milieu. Second, a more strategic, and collectively studied use of multi-apping has been adopted as a way to 'punish' a company (rewarding other competitors) and counter measures that increase drivers' fragility and precariousness. ${ }^{26}$ Third, an exploratory approach has been adopted to the possibilities offered by the diversification of the transportation ecosystem and the investments that Uber itself made, during the pandemic, in contiguous sectors, making the membranes that separated the subsystems of logistics, food-delivery and multi-modal transportation of people more porous. During the pandemic, it became increasingly common for TVDE drivers to temporarily decided to work as food-delivery riders, or to transport goods through 'Uber Connects'.

\section{The pandemic and the restructuring of the TVDE sector}

It appears that the 2020 crisis has been strategically used by Uber to reinforce its dominant position in a broader series of gig economy activities, and that Lisbon was a strategic experiment on which the platform could build. The diversification of offers has undoubtedly been strengthened by the pandemic emergency, creating a need to move the almost 27,000 potential drivers ${ }^{27}$ and 8,000 partner enterprises to new kinds of activity such as business-to-business services (like Drop-off, launched in March $2020^{28}$ ), micro-logistics (covered by Uber Connect, ${ }^{29}$ opened in June 2020 to transport small goods) and food delivery (Uber Eats).

Uber Eats established a presence in Portugal in November 2017 (when it only had agreements in Lisbon with 90 restaurants) but had expanded to $50 \%$ of Portuguese cities by June 2020, with 6,000 partners: ${ }^{30}$ Just in the first three months of 2020 , requests grew by $160 \%$ thanks also to a boosting measure that, at the beginning of the pandemic, offered fee-less services and contactless-deliveries for three weeks. ${ }^{31}$ This can be seen as a flagship expansion into an expanding market, ${ }^{32}$ that its general manager aims to transform into an 'Uber everything' (or an 'Amazon of immediate delivery'33) in 2021, leading to an important change in Uber's core business, which is being piloted in Portugal. This can be conceived almost as a mission pursued by Uber's managers ${ }^{34}$ that could be welcomed as a contribution to increasing the survival rate of Portuguese firms

\footnotetext{
26 This happens despite almost all the interviewees in the PLUS Project recognise that Uber offer a more 'stimulating' environment to work

27 https://www.publico.pt/interactivo/portugal-meio-gas-que-mudou-pais-suspenso

28 https://eco.sapo.pt/2020/03/27/uber-eats-vai-ter-mercearia-no-catalogo-motoristas-da-uber-faraoentregas-dos-hipermercados

29 https://www.uber.com/pt/blog/uberconnectpt/

30 https://jornaleconomico.sapo.pt/noticias/operacao-da-uber-eats-ja-cobre-mais-de-50-da-populacaoportuguesa-598909

31 https://eco.sapo.pt/2020/03/16/uber-eats-entrega-almocos-sem-contacto-nem-taxa-de-entrega

32 Among competitors - beyond international brands as Glovo, Takeaway and Bolt Food (opened in the fall of 2020) - there are also local players, such as NoMenu, SendEAT, Ericeira Eats.

33 See interview to Diogo Aires Conceição in: https://eco.sapo.pt/entrevista/

em-2021-queremos-passar-de-eats-para-distribuir-tudo-diz-o-novo-general-manager-da-uber-eats/

34 See the interview with a Portuguese CEO made in June 2020: https://eco.sapo.pt/entrevista/manuel-pinada-uber-o-compromisso-de-contratar-em-2020-ainda-nao-mudou-mas-vivemos-tempos-muito-incertos/
} 
during the crisis by providing continual access to customers (Raj et al., 2020), and technological tools and marketing spaces to better develop small businesses (Barbosa \& Amaral, 2020), which can offer access to new interesting big data.

The Uber marketing strategies linked to such a 'missionary imaginary' are coherent. They can be exemplified by the case of the Uber Medics programme (offering rides and meal transportation for free, and then discounts for all medical personnel in Portugal ${ }^{35}$ ) or of the agreement with the Red Cross for supporting the Vaccination Plan against COVID-19. ${ }^{36}$ A further example is the partnership with the Union of Trade and Services Associations (UACS) and the Association of Shop-keepers of Porto (ACP) for a Christmas campaign in support of local trade in the cities of Lisbon and Porto. ${ }^{37}$ Such campaigns can also produce an important internal benefit, as they contribute to increasing the congruence and self-identification of workers with the company's goals and projected image, which, according to the literature, has traditionally been rated very low by workers compared to other sectors of the economy (Gleim et al., 2019).

To depict the diversification strategy in its complexity and contradictions, it is worth noting four key developments that took place in 2020: first, Uber announced the coverage of the whole of Portugal with its cars; ${ }^{38}$ second, Lisbon joined the cities covered by the 'Movement.uber.com' platform, which aggregates data from cities, predicting traffic flows and understanding mobility; third, the assets in the bike-sharing company Jump ${ }^{39}$ were sold to Lime, as the result of an injection of 170 billion US dollars in Lime, led by Uber itself ${ }^{40}$ (the same strategy was used in the sale of the Advanced Technologies Group which researches self-driving cars ${ }^{41}$ ); and fourth, all Lime micro-mobility devices were strategically inserted into Uber's App, to maintain a pivotal role in multi-modal approaches to mobility, ${ }^{42}$ into which the municipality of Lisbon is also investing efforts, especially after the creation of the Metropolitan Integrated Mobility Pass.

Some of the new activities whose openings or expansions were accelerated by the pandemic seem to have contributed to a sort of 'oligopolistic drift'43 among the major TVDE partners of Uber. At the beginning of the COVID outbreak,

\footnotetext{
35 https://www.uber.com/pt/blog/ubermedicspt

36 https://www.uber.com/pt/blog/uber-cruz-vermelha-portuguesa-apoio-plano-vacinacao/

37 Between 9 and 24 December, Uber offered travel discounts to users who made their

purchases in stores participating in the initiative. See https://www.distribuicaohoje.com/retalho/

uber-lanca-campanha-para-apoiar-comercio-local-de-lisboa-e-porto

38 This happened in July. See https://www.uber.com/pt/blog/uberemtodoopais/

39 Uber used Lisbon as a test to diversify its business, investing in the Jump electric bicycle sharing service,

which in July already counted on 1750 units manufactured in Águeda (Rocha, 2019).

40 This happened in June. See https://eco.sapo.pt/2020/06/16/

lime-da-o-salto-compra-a-uber-as-bicicletas-jump-na-europa/

41 Uber invested billions of dollars over the years in research on self-driving technology since at least 2015. ATG was sold to startup Aurora, also a specialist in autonomous cars, after Uber had invested US \$ 400 million in Aurora (where Uber CEO D. Khosrowshahi holds a seat on the startup's board of directors). See: https://www.startse.com/ noticia/nova-economia/a-uber-desistiu-dos-carros-autonomos?fbclid=IwAR0p_kHxJAN58k8563YcDaBte32nP-ypQ bTZgv2GZyEptlRAcVuCoN3mrps

42 See declarations of Giovanna D’Esposito, Uber's General Manager for Southwest Europe. https:// observador.pt/especiais/uber-quer-transportes-publicos-na-app-portuguesa-portugal-e-um-dos-nossosmodelos-de-ouro/. Last access: 20 December 2020.

43 We could define it as 'near-monopolistic', paraphrasing Crouch (2019).
} 
business-to-business services and Uber Connect had already been entrusted in practice to the BlueWalk Lda company, under signed agreements with big supermarket chains such as Continente and Mercadona/Pingo Doce.

\section{Looking into new opportunities}

The pandemic outbreak has exposed companies operating in the gig economy to new challenges (The Fairwork Project, 2020; Huws, 2020). They were forced to abandon their comfort zones, both in terms of relations with the city and their relations with their partners/workers who constitute the indispensable source of their business as 'technological connectors' (as they always claim to be) between the demand and the provision of services (Katta et al., 2020).

Somehow, the COVID-19 pandemic can be seen not only as the stage when this shift started to happen, but also as one of the main factors that leveraged it. In fact, the pandemic can be seen at the roots of three important dynamics, which strengthened the centrality, visibility and contractual strength of those that provide services through their material labour.

First, the growing competition for scarce resources among companies operating in the same sector intermittently raised the negotiating capacity of workers, thanks to the multi-apping mechanism (which is a distinctive feature of the platform economy, offering the opportunity for partner/workers to migrate to competitors if they offer better deals and/or working conditions). However, at other moments the companies' tug-of-war took advantage of the unregulated number of available drivers to unilaterally reduce their earning.

Second, the pandemic conditions exposed the vulnerability of precarious labour ties and consequent lack of social protection guarantees. This created a new focus on the growth of empty time-lapses between the scattered 'parentheses of work. ${ }^{44}$ These enforced periods of inactivity provided an opportunity for partner/workers to strengthen and tighten connectivity among themselves (via social media platforms such as WhatsApp or Telegram), while collaborating with advocacy agents to provide mutual help and compensate for the absence of a direct dialogue with the platform.

Third, workers became increasingly aware of their importance - both for the platform's survival and (at least in the case of transportation platforms) for the urban ecosystem and the safety of citizens - fuelled by the unusual support offered by government action and by the companies, which were seen as a recognition of their character as essential players. This occurred in a social environment where the notion and the imaginary of 'care-taking' are slowly evolving, feeding new dynamics of congruence and self-congruence (traditionally considered marginalised in the gig economy) between the partner/workers, their perceived social mission and the image of the platform they work for.

Establishing a clear cause-effect relationship between the pandemic and these dynamics is impossible, as many other contributory causes blur the legibility of what occurred during 2020. Nevertheless, it is clear that there is a widespread perception that

44 Notion taken from an interview with an Indian Uber driver (with no ownership of cars), collected on 8 December 2020. 
the COVID-19 outbreak questioned the 'apparent solidity of the Portuguese scenario' 45 and made an augmented protagonism possible for workers, indicating a new future direction. In this context, the pandemic can best be viewed not as a parenthesis between a previous normality and an attempt to return to something similar, ${ }^{46}$ but as 'a point of no return, ${ }^{47}$ whose legacy might be to reduce the asymmetries existing in the relations between platforms and different types of partner/workers.

In this respect, the autumn of 2020 (when the second wave of COVID-19 contagions obliged the government to adopt new restrictive measures) brought several surprises, announcing a turning point in the relationship between gig platforms, the broader society and their partners/workers. This can be illustrated by a series of events.

First, in October 2020, a supporting document of the 2021 state budget announced that the government is working on an urgent law proposal to increase the protection and strengthen the contractual positions of gig workers, respecting EC and ILO guidelines, reinforcing transparency and access to information and allowing for adequate inspection mechanisms. ${ }^{48}$

Second, in mid-November 2020, the Mayor of Lisbon declared that he would file a complaint with the Competition Authority against platforms such as Glovo and Uber Eats, for the high fees imposed on restaurants when providing home delivery services. ${ }^{49}$ Calling their 'predatory approach [.. . ] revolting and shameful', he declared that he is not 'particularly concerned with the survival of these businesses' and that the city is working on an alternative platform that could have no costs for local commerce. This would be in line with what Bologna, Milan and other cities have committed to in political networks such as $\mathrm{C} 40$ or Cities for Adequate Housing. ${ }^{50}$ In parallel, Lisbon Municipality is working on a mobility-as-service platform initiative, which would integrate private offers and public transportation, 'with a pivotal focus on the latter. ${ }^{51}$

Third, in November, the 6th Parliamentary Committee on Economy, Innovation, Public Works and Housing (CEIOPH) received the Workbook of Claims of TVDE drivers, and started to compose the Working Group for the Revision of Law 45/2018. Other institutions started working on the contiguous issue: i.e. the Institute of Mobility and

45 See Leonardi and Pirina (2020).

46 As Santos wrote (2020a: 2): coronavirus fed 'the pessimistic strand of contemporaneity and this must be taken into account in the immediately post-pandemic period. Many people will not want to think about alternatives to a more virus-free world. They will want to return to normal at all costs because are convinced that any change will be for the worse. The narrative of fear must be contrasted with the narrative of hope. The dispute between the two narratives will be decisive. How it is decided will determine whether or not we want to continue to be entitled to a better future'.

47 Interview with a member of the Lisbon City council, collected on 15 December 2020.

48 See the interview with the Secretary of State for Employment, Miguel Cabrita. https://expresso.pt/ economia/2020-10-23-Governo-prepara-lei-Uber-para-reforcar-direitos-dos-trabalhadores-das-plataformas-digitais 49 https://www.nit.pt/fora-de-casa/na-cidade/medina-vai-fazer-queixa-da-ubereats-e-quer-criar-umaalternativa-para-os-restaurantes and https://observador.pt/2020/11/20/medina-abre-guerra-com-aubereats-e-promete-alternativa-sem-custos-para-restaurantes/?fbclid=IwAR1DLEs5atwh6yA5fZ41mEYy4 uaV_LbOzWnTPLKMttv7HCHPfqrleNeuYuY

50 See https://www.produzionidalbasso.com/project/so-de-il-delivery-sociale and https://www. fondazioneinnovazioneurbana.it/45-uncategorised/2258-un-alternativa-etica-per-le-consegne-a-domicilio-abologna-e-possibile-coniugare-mutualismo-e-piattaforme-assemblea-pubblica

51 Representative of Lisbon Mobility Department during Sopolab 1 - PLUS Portugal, held on 27 December 2020. 
Transport completed the Preliminary Report of the Working Group for Modernisation focused on taxis (including a hypothesis of a special regime for platform services). ${ }^{52}$

Fourth, on 25 November 2020, the Minister of Labour presented the Basic Document for the 'Green Paper on the Future of Work', whose recommendations also discuss how 'atypical' platforms' workers will share opportunities for social protection, social dialogue and collective contracting. She added that these topics will be prioritised during the next Portuguese presidency of the EU in 2021 and in Porto's Social Summit to be held on 7 May 2021. Recent interviews with Uber managers demonstrate that the company was neither directly informed, nor consulted, during this process. ${ }^{53}$

Fifth, in December, the Lisbon City Council activated a Local Accommodation Mixed Commission (applicable since November 2019) that will collect data from other gig-economy giants (such as Airbnb) in order to shape more evidence-based and data-driven urban policies. ${ }^{54}$ Meanwhile AMT (the Authority for Mobility and Transport) put the revised ruling documents on data collection and transmission on public display, including the platforms' data.

Sixth, in mid-December 2020, the Ministries of Infrastructures and of the Environment - following the Mobility and Transportation Authority (AMT) and the Institute of Transports and Mobility (IMT) - received the Working Group of STRUP/ CGTP Union in charge of the Claims Workbook of TVDE drivers, ${ }^{55}$ and facilitated their meeting with Uber's public policies manager, held on 22 December.

Taken together, such initiatives announce a major shift that apparently cracks the subservient approach to gig investors previously common among politicians. It appears to introduce the ambition of exerting a certain control of private entrepreneurship to foster platform workers' rights and genuinely prioritise the common good while managing the city of Lisbon. From this perspective, clear requests from different spaces are converging in the direction of asking that the revision of the regulatory framework could articulate not around equal provisions based on a social-security-for-all scheme; but could be considered as an equity-based approach, grounded on the recognition of the differentiated impacts (made visible by the COVID-19 outbreak) that changes in the market trends can generate among the diverse range of players depicted in Table 1, and their different types of contracts and profiles of investment and risks.

The revision of Law 45/2018 and the final version of the Green Book of Work (to be published in 2021) constitute an unmissable opportunity to develop still unexplored potentials. As one TVDE partner we interviewed put it:

We have two huge opportunities. One is rethinking the drivers' contractual position, which is unfair for workers, at least for all those who depend completely on TVDE work, and cannot be correctly defined as 'independent'. The other is to discuss some

\footnotetext{
52 Despacho $n^{\circ} 6560 / 2020$, of 23 June 2020.

53 https://eco.sapo.pt/entrevista/em-2021-queremos-passar-de-eats-para-distribuir-tudo-diz-o-novo-generalmanager-da-uber-eats

54 Interview with a member of the 5th Commission of Lisbon City Council, held on 15 December 2020.

55 http://www.cgtp.pt/accao-e-luta-geral/15304-grupo-de-trabalho-fez-avancar-caderno-reivindicativo-dosparceiros-e-motoristas-tvde-strup?fbclid=IwAR3Mn1E67 pojribT8F1xbUYBGFoBSYl-seTJF3l2bAWub BjK3uoxTSrk4eQ
} 
parts of the algorithm, for example its dynamic nature, which is unfair for clients; the performance evaluation that creates urban myths and unacceptable psychological pressure because its exact consequences are not explained to drivers [. . .] But we also must discuss where data goes and how it's used because they say data serves to make improvements, which we can't see clearly. Improvements for whom? [. . .] While doing this, we cannot look only to the Portuguese experience, but we must open our eyes to the world. For example, did you see what happened in California? California was a good model for gradually increasing drivers' rights, especially during COVID-19.56 Then, Uber invested millions in a referendum, and again we lost our rights through a democratic tool: clients determined our destiny convinced by Uber lies. We have to be careful here in Portugal: the pressure that Uber is under can prevent improvement of the Uber Law $[\ldots]^{57}$

From this perspective, another important change of pace to be anchored to the pandemic emergency is the possibility of using data produced by platform interactions to improve public institutions and help workers and other stakeholders to shape more effective policies for the gig sector, by carefully monitoring their effects. The recent creation of new institutional figures in charge of overseeing some sectors where platforms operate (such as the Lisbon Commission on Local Accommodation and the Mobility and Transport Authority) is coherent with the legislation enacted in recent years, which has aimed, among other things, to create new information systems that could foster more data-driven decisions and an institutional capacity for responding with just-in-time measures to problems emerging in these policy areas.

For sure, such institutions will have to struggle to obtain meaningful data from the platform giants, and learn to use them to monitor the laws' application and envisage ways to transform them in tight collaboration not only with the entire public governance structure, but also with trade unions, social movements and academic institutions.

\section{Final remarks}

The pandemic breakout has exposed the contradictions of the Portuguese urban economic recovery model of the last decade. Grounded in the dynamics of real estate and the touristification of urban territory, ${ }^{58}$ this has generated rapid growth accompanied by reduced environmental, social and economic sustainability. The pandemic period has also reconfirmed that Portugal can be seen as a laboratory for what Leonardi and Pirina (2020) have defined as varieties of gig economy, shaped by a fruitful dialogue between digital platforms and political institutions' and based on an 'intermediary platform capitalism ${ }^{59}$ which encourages the proliferation of poorly protected working relationships along its chain of command.

\footnotetext{
56 The interviewee refers to Proposition 22, put on vote on 3 November 2020. Around $58.63 \%$ of voters chose to abolish new norms to regulate the contractual relation between transportation apps and workers in the state. See: https://ballotpedia.org/California_Proposition_22,_App-Based_Drivers_as_Contractors_and_Labor_Policies_ Initiative_(2020)

57 Interview with an Uber partner (38 years old, with 3 cars) held in Lisbon on 10 December 2020.

58 See Santos (2019); Teles (2018); Rodrigues et al. (2016).

59 See Rodrigues et al. (2021).
} 
In Lisbon, the COVID-19 emergency, an 'apocalypse in slow motion', whose non-linear time alternated fears and hopes of future normalisation, ${ }^{60}$ saw the growth of newly equipped social movements and unexpected strengthening of the dynamics of syndicalisation. Workers contested the poorly-conceived assistance packages created by the government for employees and entrepreneurs, as well as the prevalence of a nostalgic imaginary of the recent recovery, based on a degradation of working skills and relations, uncritical incentives to any form of foreign investment, and a rent-based, extractivist and predatory model of austerity urbanism. ${ }^{61}$

The major location-based platforms (such as Uber) that proliferated in Portugal in the aftermath of the 2008-2014 crisis were destabilised not only by the shocking shrinkage of their markets, but also by the difficulty of maintaining their tactical deployment of 'conjunctural geographies,'62 which allowed them to reduce their embeddedness in the urban fabric and partially evade local norms and regulations.

When those whom they define as platform partners (and to whom they deny the status of workers) started losing a vital income stream on account of mobility restrictions, and their vulnerability became more evident, companies felt compelled by mounting public pressure to institute financial assistance policies that - although delayed and inadequate - represented a substantial deviation from their normal modus operandi. These sort of employment protections - admitting some responsibility for drivers' physical conditions - demonstrated a capacity to improve them. So, the pandemic ended up highlighting 'the myriad tethers that materially embed [these companies] to people and places' (Katta et al., 2020: 206), and demonstrated that disembeddedness and commodification of labour were strategies that resulted from a choice that has now been implicitly revealed to be reversible.

Political institutions, imprisoned in their inabilities to function normally, for several months, waited for a re-normalisation of sanitary conditions which could turn back the clock and restart business as usual from the outbreak's interruption. Following this perspective, initially, COVID-19 remained an untapped opportunity for a paradigm change (forced by institutional commitment) in the relations between gig-economy giants, their workers and the urban environment. This represented a paradox and another lost opportunity for a state that, since the first declaration of the State of Emergency, had rhetorically claimed its centrality over any other driving forces of society, but then did not use these 'broadest legislative powers ever seen in peacetime' (IPU, 2020: 7).

However, something changed in the autumn of 2020, with the last word still unwritten. Indeed, politics received stimuli from media pressure, oversight of independent authorities and several forms of 'counter-democracy' (Rosanvallon, 2018; Sorice, 2019), together with participatory processes which - in the Lisbon case - operated both through forms of participation 'by invitation' and those 'by irruption' (Blas \& Ibarra, 2006). Moreover,

60 See Santos (2020a).

61 See Mendes (2020) and Falanga et al. (2019).

62 Graham, 2020. 
the pandemic itself, concentrating public attention and the intra-party debate on a thinner agenda and a more reduced and focused number of topics, created a unique opportunity for who intends to reframe any polity issue in strict relation with basic rights, like housing, social protection and security of employment. ${ }^{63}$

Only in 2021, with the concretisation (or not) into legislative measures and policies (well implemented and carefully monitored) of the bombastic announcements made in the last months of 2020 made by powerful politicians at different levels, will tell if the apparent change of pace is real. At the time of writing, a groundbreaking discursive shift in institutional positions must be registered, at least. For the first time, at the centre of the debate there is a shared recognition that public intervention is necessary to regulate the sectors in which the gig economy operates, and it has become clear that 'their pretension of dictating the rules' 64 will be examined more critically after the pandemic. This was summarised by a female TVDE driver who told us:

We all agree that 2020 was a [expletive] year. But let's make it an exercise of collective memory [. . . I It started with a huge TVDE strike against the unilateral lowering of fares by the Uber giant, acting as a mincer grinder... And it ended with another massive strike against a more vulnerable company, which is actually mostly ignored by the government, when they are preparing for a revision of 'Uber Law' and other measures to tackle our precariousness [. . .] Maybe we cannot trust politicians, but we can bet on our capacity to obtain our needs. We have been clever in 2020, using the suffering brought by COVID to fight. And maybe, together with the COVID vaccine, also a vaccine for our unsustainable working situation will become available. ${ }^{65}$

If the present direction is confirmed, Lisbon's experience could have played a significant piloting role for the entire country (now that TVDE platforms are operating nationwide), but is also valuable for informing the development of innovative ways for regulating the gig economy elsewhere. In this perspective, granting the elaboration of a 'shared memory' or 'a community of memories' (Horton, 2020b: 1750) about the lessons learned from COVID-19 could make an important contribution to building a bridge to a brighter future.

(C) Giovanni Allegretti, Sheila Holz and Nuno Rodrigues, 2021

\section{ACKNOWLEDGEMENTS}

The research reported in this paper was funded by European Union, Horizon 2020 research and innovation programme, 'Platform Labour in Urban Spaces: Fairness, Welfare, Development' (https://project-plus.eu), Grant Agreement No. 822638. The views and opinions expressed in this publication are the authors' sole responsibility and do not necessarily reflect the views of the European Commission/Research Executive Agency.

63 Interview with a Portuguese MP, collected on 23 December 2020.

64 Interview with a Portuguese MP, collected on 21 December 2020.

65 Interview with a female Brazilian TVDE driver, collected on 8 December 2020. 


\section{REFERENCES}

Baganha M.I. (2001). 'A cada Sul o seu Norte: dinâmicas migratórias em Portugal', in B. Santos (eds), Globalização: fatalidade ou utopia?, Porto: Edições Afrontamento:135-159.

Barbosa M. \& H. Amaral (2020). 'Em 2021 "queremos passar de Eats para distribuir tudo", diz o novo general manager da Uber Eats', Eco.Pessoas, 1 December.

Belchior, T. (2020). Intervention in the Round Table 'As plataformas digitais e o futuro do trabalho', Lisbon, 12 November. https://colabor.pt/agenda/12-novembro-2020-plataformasdigitais-futuro-trabalho/ (minute 2:56-57).

Belger, T. (2020). 'Coronavirus: Gig workers sue UK government over support for self-employed', Yahoo! Finance, 8 May. https://uk.finance.yahoo.com/news/coronavirus-uber-legal-actiongig-workers-sue-uk-government-rights-230055092.html

Bellon, T. \& N. Balu (2020). 'Coronavirus exposes U.S. Uber, Lyft drivers' lack of safety net', Reuters, 25 March. https://uk.reuters.com/article/uk-health-coronavirus-uber-lyftidUKKBN21C20X

Blas, A., \& P. Ibarra (2006). 'La participación: estado de la cuestión', Cuadernos de Trabajo de Hegoa, 39 (January).

Carvalho, L. \& M. Vale (2018). 'From participation to startup urbanisation? Re-situating open data in Lisbon', in A. Karvonen, F. Cugurullo, \& F. Caprotti (eds), Inside smart cities: place, politics and urban innovation, Abingdon: Routledge:211-226.

Crouch, C. (2019). Will the gig economy prevail? London: Polity Press.

Demary, V., B. Engels \& C. Rusche (2020). Differentiated treatment of business users by online platforms - an analysis of incentives with an in-depth look at app stores and e-commerce platforms, Brussels: Observatory on the Online Platform Economy.

Falanga, R., S. Tulumello, A. Inch, A.R. Alves, S. Jorge, J. Kühne \& R. Silva (2019). 'The "Caravana pelo Direito à Habitação”: Towards a new movement for housing in Portugal?' Radical Housing Journal, 1 (1):171-187.

Gineikytė, V., E. Barcevičius \& G. Cibaite (2020). 'PPMI analytical paper 5: Business user and thirdparty access to online platform data', Brussels: Observatory on the Online Platform Economy

Gleim, M., C. Johnson \& S. Lawson (2019). 'Sharers and sellers: A multi-group examination of gig economy workers’ perceptions', Journal of Business Research, 98 (2019):142-152.

Graham, M. (2020). 'Regulate, replicate, and resist - the conjunctural geographies of platform urbanism', Urban Geography, 41 (3):453-457.

Horton, R. (2020a). The Covid-19 catastrophe: What's gone wrong and how to stop it happening again, London: Polity Press.

Horton, R. (2020b). 'COVID-19 and the ethics of memory', The Lancet, 395 (6 June):1750. www. thelancet.com

Huws, U. (2006). 'Fixed, footloose or fractured: Work, identity, and the spatial division of labor', Monthly Review, 57 (10), March.

Huws, U. (2014). Labor in the global digital economy. The cybertariat comes of age, New York: NYU Press.

Huws, U. (2019). Labour in contemporary capitalism - what next? London: Palgrave Macmillan.

Huws, U. (2020). 'The algorithm and the city: Platform labour and the urban environment', Work Organisation, Labour \& Globalisation, 14 (1):14. doi: 10.13169/workorgalaboglob.14.1.0007

ILO (2019). 'Digital labour platforms and the future of work: Towards decent work in the online world', Geneva: ILO.

IPU (2020). 'Country compilation of parliamentary responses to the pandemic', InterParliamentary Union report, 17 April.

Katta, S., A. Badger, M. Graham, K. Howson, F. Ustek-Spilda \& A. Bertolini (2020). '(Dis)embeddedness and (de)commodification: COVID-19, Uber, and the unravelling logics of the gig economy', Dialogues in Human Geography, 10 (2):203-207.

Kerr, D (2020). 'Uber expands drivers' COVID-19 sick pay by a little bit after being sued', CNET, 1 May. Available at https://www.cnet.com/news/uber-expands-driver-sick-pay-by-a-little-bitafter-being-sued 
Kuhn, K. (2016). 'The rise of the 'gig economy' and implications for understanding work and workers', Industrial and Organisational Psychology, 9 (1):157-162. doi: 10.1017/iop.2015.129

Leonardi, E. \& G. Pirina (2020). 'Uber in the Portuguese gig economy: A laboratory for platform capitalism', Work Organisation, Labour \& Globalisation, 14 (2) (2020):46-63.

LUSA (2018). 'Chauffeur Privé chega a Lisboa. Lei da Uber dá "segurança”', Jornal de Negocios, 17 September. https://www.jornaldenegocios.pt/empresas/detalhe/chauffeur-prive-chega-alisboa-lei-da-uber-da-seguranca

MacKenzie, D. (2020). Covid-19: The pandemic that never should have happened and how to stop the next one, London: Hachette Books.

Mendes, L. (2020). 'How can we quarantine without a Home? Responses of activism and urban social movements in times of COVID-19 pandemic crisis in Lisbon', Tijdschrift voor Economische en Sociale Geografie, 111 (3), June 2020. doi: 10.1111/tesg.12450

Nath, B. (2020). 'What books on the pandemic, published during and after the lockdown, are telling us about Covid-19'. Scroll-in, 28 October. https://scroll.in/article/976948/what-bookson-the-pandemic-published-during-and-after-the-lockdown-are-telling-us-about-covid-19

Polkowska, D. (2020). 'Platform work during the COVID-19 pandemic: A case study of glovo couriers in Poland', European Societies. doi: 10.1080/14616696.2020.1826554

PLUS Portugal (2019). City Report, Lisbon, Coimbra: CES/PLUS.

Raj, M., A. Sundararajan \& C. You (2020). 'COVID-19 and digital resilience: Evidence from Uber Eats', ArXiv, 12 June. https://ssrn.com/abstract=3625638; doi: 10.2139/ssrn.3625638

Rani, U. \& R.K. Dhir (2020). 'Platform work and the COVID-19 pandemic', Indian J. Labour Econ., 63:163-171. doi: 10.1007/s41027-020-00273-y

Reitano, T. \& M. Shaw (2021). Criminal contagion: How Mafias, gangsters and scammers profit from a pandemic. Oxford: Oxford University Press.

Rocha, C. (2019). 'Uber quer contratar mais 200 pessoas para centro tecnológico em Portugal', DN Insider, 4 July. https://insider.dn.pt/noticias/uber-quer-contratar-mais-200-pessoas-paracentro-tecnologico-em-portugal/19964

Rodrigues, J., A.C. Santos \& N. Teles (2016). A Financeirização do Capitalismo em Portugal, Lisbon: Observatório sobre Crises e Alternativas/CES.

Rodrigues, N., M. Secchi \& F. Tomassoni (2021). 'Lisbon, Uber and the intermediary platform capitalism: Preliminary assessment of the effect of covid-19 outbreak', Finisterrae, January.

Romo, V (2020). 'Self-employed and gig workers face long waits for coronavirus relief checks', NPR, 17 April. Accessed 13 May 2020. https://www.npr.org/2020/04/17/836670935/selfemployed-and-gig-workers-face-long-waits-for-coronavirus-relief-checks

Rosanvallon, P. (2018). Counter-democracy. Politics in an age of distrust, Cambridge: Cambridge University Press.

Rosenblat, A. (2018). Uberland: How algorithms are rewriting the rules of work, Berkeley: University of California Press.

Santos, A.C. (2019, coord.). A nova questão da habitação em Portugal. Lisbon: Observatorio sobre crises e Alternativas/CES-Actual.

Santos, B. (2020a). 'O coronavírus, nosso contemporâneo', Sul 21, 17 May.

Santos, B. (2020b). A Cruel Pedagogia do Vírus, Coimbra: Almedina.

Seixas, J., S. Tulumello, S. Corvelo \& A. Drago (2015). 'Dinâmicas sociogeográficas e políticas na Área Metropolitana de Lisboa em tempos de crise e de austeridade', Cadernos Metrópole, 17 (34):371-399. doi: 10.1590/2236-9996.2015-3404

Sigala, M. (2020). 'Tourism and COVID-19: Impacts and implications for advancing and resetting industry and research', Journal of Business Research, 117:312-321.

Sims, J. (2020), 'Will coronavirus change how we define heroes?' BBC, 24 April. https://www.bbc. com/worklife/article/20200422-will-coronavirus-change-how-we-define-heroes

Slee T. (2017). Uberização: a nova onda do trabalho precarizado, São Paulo: Elefante.

Sorice, M. (2019). Partecipazione democratica. Teorie e problem, Milan: Mondadori Università.

Snowden, F. (2020). Epidemics and society: From the Black Death to the present, Princeton: Yale University Press. 
Sonnemaker, T. (2020). 'An uber driver who got COVID-19 couldn't get the company to cover his promised sick pay', Business Insider Australia, 26 March. Accessed 13 May 2020. https:// www.businessinsider.com.au/uber-driver-coronavirus-sick-pay-ceo-dara-khosrowshahitwitter-2020-3

Spurk, D. \& C. Straub (2020). 'Flexible Employment relationships and careers in times of the COVID-19 pandemic', Journal of Vocational Behavior. Accessed 12 Aug 2020. doi: 10.1016/j. jvb.2020.103435

Srnicek, N. (2017). Platform capitalism, London: John Wiley \& Sons.

Stephany, F., M. Dunn, S. Sawyer \& V. Lehdonvirta (2020). 'Distancing bonus or downscaling Loss? The changing livelihood Of US online workers in times of COVID-19', Tijdschrift Voor Economische en Sociale Geografie, 111 (3):561-573.

Teles, N. (2018). The Portuguese Illusion, Jacobin, 7 February.

The Fairwork Project (2020). 'The gig economy and Covid-19: Looking ahead'. Updated Version September 2020. Fairwork Report on Platform Policies. https://fair.work/wp-content/uploads/ sites/97/2020/06/COVID19-Report-Final.pdf

Tomassoni, F. \& G. Pirina (2019). 'Portugal: um laboratório para Uber', Le Monde Diplomatique, Portuguese edition, November.

UCSC (2020). 'Already vulnerable, gig economy workers in san francisco suffer during pandemic, survey finds. ScienceDaily, 5 May. Accessed 13 May 2020. www.sciencedaily.com/ releases/2020/05/200505093116.htm

Zizek, S. (2020). Pan(dem)ic! COVID-19 Shakes the World, London: Polity Press. 